\title{
Pemberdayaan Masyarakat Melalui Pemanfaatan Tanah Pekarangan (PTP) untuk Konservasi dan Wirausaha Agribisnis di Kelurahan Kedung Pane Kota Semarang
}

\author{
Sugiarso, Agus Riyadi, Rusmadi \\ Universitas Islam Negeri Walisongo Semarang \\ Email: sugiarso@walisongo.ac.id:
}

\begin{abstract}
Community empowerment activity through Lecturer Dedication Program (KPD) utilization of yard for conservation and agribusiness this is the first step to stimulate the growth of spirit of self-help and community participation. KPD program is a step to build the foundation for a social change that led to empowering society (empowering society). Some changes that have been achieved through this KPD program are: 1) The occurrence of mental attitude changes and mindset (mindset) and entrepreneurial spirit on the subject of assistance, so that they are aware of the local potential around him that can be developed into a high value commodity. 2) The occurrence of changes and the creation of habituation of the working patterns of the targeted subjects which put forward the concept of hard and intelligent work, which in the end is expected to increase productivity. 3) The birth of assisted subjects who have a set of knowledge and skills (life skills) to develop local potentials into commodities of production with higher selling value.
\end{abstract}

Abstrak: Kegiatan pemberdayaan masyarakat melalui program Karya Pengabdian Dosen (KPD) pemanfaatan pekarangan untuk konservasi dan agribisnis ini merupakan langkah awal untuk merangsang tumbuhnya semangat swadaya dan partisipasi masyarakat. Program KPD merupakan tahapan untuk membangun pondasi bagi sebuah perubahan sosial yang berujung pada pemberdayaan masyarakat (empowering society). Beberapa perubahan yang sudah dicapai melalui program KPD ini adalah: 1) Terjadinya perubahan sikap mental dan pola pikir (mindset) dan jiwa entrepreneur pada subyek dampingan, sehingga mereka sadar akan adanya potensi lokal di sekelilingnya yang bisa dikembangkan menjadi komuditas yang bernilai jual tinggi. 2) Terjadinya perubahan dan terciptanya habituasi pola kerja subyek dampingan yang mengedepankan konsep kerja keras dan cerdas, yang pada akhirnya diharapkan dapat meningkatkan produktifitas. 3) Lahirnya subyek dampingan yang memiliki seperangkat pengetahuan dan ketrampilan (life skill) untuk mengembangkan potensi lokal menjadi komoditas hasil produksi yang memiliki nilai jual lebih tinggi.

Kata Kunci: konservasi, tanah pekarangan, wirausaha agribisnis. 


\section{PENDAHULUAN}

Pertumbuhan perkotaan yang tidak terkedali telah menyebabkan banyak permasalahan, baik ekonomi, sosial, maupun lingkungan. Hal ini dikarenakan pertumbuhan perkotaan membutuhkan ruang berupa lahan untuk pemukiman. Oleh karenanya, masalah ketersediaan lahan akan menjadi masalah yang sangat serius di masa-masa yang akan datang. Pada saat yang sama, pertumbuhan perkotaan juga menyebabkan masalah lain, yakni terlampauinya daya dukung dan daya tampung lingkungan, karena pemukiman yang semakin padat akan mempengaruhi sistem prasarana dan sarana di perkotaan maupun di pedesaan seiring dengan adanya perubahan fungsi lahan untuk permukiman. Kejadian yang paling sering dialami adalah terjadinya banjir pada saat penghujan, tetapi pada saat musim kemarau akan mengalami kekeringan. Banjir bisa disebabkan karena minimnya daerah resapan air, sehingga air tidak dapat masuk ke dalam tanah, melainkan akan menjadi air aliran. Pada debit yang cukup tinggi, air hujan akan menjadi air larian yang menyebabkan banjir. Sementara pada saat musim kemarau, akibat tidak adanya air yang meresap ke dalam tanah maka menyebabkan daerah bagian atas menjadi kering.

Selain telah menyebabkan terlampauinya daya dukung dan daya tampung lingkungan, minimnya ketersediaan lahan akibat pertumbuhan permukiman di perkotaan juga menyebabkan masalah lain, yakni ketahanan pangan, terutama ketahanan pangan keluarga. Contoh yang paling sederhana adalah begitu tergantungnya masyarakat akan kebutuhan sayur dan bahan bumbu dapur seperti cabai dan kangkung dari pasar. Pada saat harga cabai melambung tinggi para ibu rumah tangga mengalami shok. Kondisi semacam ini sebenarnya bisa ditangani dengan upaya pertanian mandiri rumah tangga dengan pemanfaatan tanah pekarangan (PTP), sehingga kebutuhan akan sayur dan bumbu dapur dapat dipenuhi secara mandiri dengan biaya yang murah dengan menggunakan teknologi tepat guna sederhana.

Berdasarkan permasalaan tersebut di atas, maka perlu dilakukan langkahlangkah strategis dalam upaya menyelesaikan terlampauinya daya dukung dan daya tampung lingkungan, dan sekaligus menyelesaikan masalah ketahanan pangan keluarga melalui program "Pemberdayaan Masyarakat Melalui Pemanfaatan Tanah Pekarangan (PTP) untuk Konservasi dan Wirausaha Aribisnis di Kelurahan Kedungpane Kecamatan Mijen Kota Semarang”. Program semacam ini merupakan program yang didasarkan pada inisiatif lokal, yang merupakan bagian dari model-model pembangunan yang dapat mensejahterakan masyarakat desa. Program pembangunan masyarakat ini tidak berpusat pada birokrasi melainkan berpusat pada masyarakat atau komunitasnya 
sendiri. Pemberian kekuasaan pada inisiatif lokal dan partisipasi masyarakat menjadi kata kunci dalam pengembangan masyarakat (Soelaiman, M. Munandar, 1998:132).

Program pemanfaatan tanah pekarangan ini dapat memiliki tiga manfaat secara sekaligus, yakni peningkatan nilai-nilai konservasi, nilai ekonomi, dan nilai ketahanan pangan. Adapun selengkapnya dijelaskan sebagaimana uraian berikut: 1) Nilai konservasi, yakni konservasi lingkungan, dimana tanah pekarangan dapat digunakan sebagai daerah resapan air melalui pembuatan lubang resapan biopori, sehingga setiap rumah tangga akan mampu melakukan konservasi air. Hal ini akan membantu recharges air ke dalam tanah sehingga akan menjadi cadangan untuk kebutuhan masyarakat pada saat musim kemarau yang kering. 2) Nilai ekonomi, yakni melalui peningkatan wirausaha agribisnis, dimana pemanfaatan lahan pekarangan dengan penanaman tanaman hortikultura seperti sayuran, bumbu-bumbu dapur, dan buah-buahan akan mendatangkan keuntungan ekonomi bagi keluarga. Pertama, kebutuhan akan sayur dan bumbu dapur dengan standar kualitas tinggi, bergizi, dan aman dapat dicukupi oleh dirinya sendiri tanpa harus membeli dari luar. Apalagi jika dilakukan secara intensif, maka dapat menghasilkan nilai ekonomi yang lebih besar karena ibu-ibu rumah tangga dapat menjual hasil petanian rumah tangga tersebut ke pasar. Kedua, pemanfaatan lahan pekarangan tidak membutuhkan banyak biaya karena didukung dengan pemanfaatan teknologi terapan sederhana, seperti misalnya pembuatan pupuk organik sendiri. 3) Nilai ketahanan pangan, melalui penanaman tanaman hortikultura seperti sayuran, bumbu-bumbu dapur, dan buah-buahan akan menjamin ketahanan pangan keluarga. Apalagi sayuran dan tanaman bumbu dapur seperti cabai, merupakan bahan pokok yang dikonsumsi setiap hari.

Program karya pengabdian dosen ini akan dilakukan di wilayah Kelurahan Kedungpane Kecamatan Mijen Kota Semarang.Pemilihan lokasi dampingan ini didasarkan beberapa alasan sebagai berikut: 1) Kelurahan Kedungpane merupakan daerah penyangga UIN Walisongo karena lokasinya berada tidak jauh dari kampus, oleh karenanya memberi manfaat kepada daerah penyangga akan mendukung kemanfaatan UIN Walisongo bagi masyarakat sekitar kampus; 2) Kelurahan Kedungpane merupakan lokasi KKN MIT 3 UIN Walisongo Semarang, yakni Posko 22; 3) Program Pemanfaatan Tanah Pekarangan (PTP) ini merupakan upaya tindak lanjut dari Program Unggulan KKN Posko 22 yang sebelumnya telah mengadakan program penyuluhan pemanfaatan lahan pekarangan untuk mewujudkan kampung tematik di wilayah Kelurahan Kedungpane; 4) Kelurahan Kedungpane merupakan daerah yang tinggi dan 
setiap rumah tangga masih memiliki tanah pekarangan rumah yang cukup, sehingga bisa dilakukan program tersebut; 5) Kelurahan Kedungpane telah memiliki inisiatif, baik dari pemerintah kelurahan, ibu-ibu PKK, dan masyarakat, untuk mewujudkan Kampung Tematik, sehingga Program Pemanfaatan Tanah Pekarangan (PTP) ini akan menjadi salah satu unggulan dari program Kampung Tematik tersebut. 6) Kelurahan Kedungpane telah memiliki kelompok masyarakat yang bergerak dibidang pengembangan desa wisata, yakni Kelompok Sadar Wisata (Pokdarwis) Kelurahan Kedungpane; 7) Masyarakat Kedungpane, melalui perwakilan ibu-ibu PKK, telah menyampaikan keinginannya untuk meminta pendampingan terkait Program Pemanfaatan Tanah Pekarangan(PTP) ini kepada Tim KPD.

\section{KONDISI LINGKUNGAN PEKARANGAN KEDUNGPANE MIJEN}

Strategi Secara administratif, Kelurahan Kedungpane merupakan bagian dari wilayah Kecamatan Mijen. Kelurahan ini terdiri dari 6 RW dan 33 RT dengan jumlah rumah tangga sebanyak 1.426 rumah. Sedangkan penduduk Kelurahan Kedungpane pada tahun 2015 sebanyak 5.309 orang yang terdiri dari 2.702 orang laki-laki dan 2.607 orang perempuan (BPS Kota Semarang, 2016). Sementara secara sosial-budaya, Kelurahan Kedungpane merupakan wilayah semi urban, dimana ia merupakan wilayah pinggiran kota. Meskipun demikian, karena berdekatan dengan kawasan industri, pusat pertumbuan Kota Baru BSB, dan juga kampus UIN Walisongo.

Kondisi tanah pekarangan di Kelurahan Kedungpane saat ini adalah tidak dimanfaatkan, atau dibiarkan kosong. Berdasarkan hasil pertemuan dengan IbuIbu PKK di Balai Kelurahan, pada umumnya karena masyarakat tidak mengetahui bagaimana cara pemanfaatan tanah pekarangan rumah tersebut, sehingga banyak di antara mereka membiarkan tanah tersebut kosong. Meskipun demikian, secara keseluruhan Kelurahan Kedungpane memiliki potensi lokal yang bisa dikembangkan, baik dari sisi pemanfaatan tanah pekarangan untuk meningkatkan nilai konservasi dan nilai ekonomi lahan.

Bahkan, Pemerintah Kecamatan Mijen mengusulkan Kelurahan Kedungpane sebagai salah satu desa wisata di Kota Semarang karena daerah ini memiliki banyak potensi untuk ditawarkan. Selain memiliki potensi sumber daya alam, kesenian dan kebudayaan, juga banyak hasil karya kerajinan dan kuliner yang dihasilkan oleh masyarakatnya. Selain memaksimalkan potensi yang dimiliki kelurahan, penetapan desa wisata akan mendukung keberadaan obyek wisata Waduk Jatibarang dan Gua Kreo. Di kelurahan ini juga sudah terbentuk masyarakat Kelompok Sadar Wisata (Pokdarwis) yang menjadi wadah 
pembinaan dan pemberdayaan masyarakat setempat untuk mendukung keberadaan desa wisata.

Berdasarkan kondisi seperti tersebut di atas, maka beberapa harapan yang ingin dicapai melalui program Karya Pengabdian Dosen (KPD) ini antara lain: pertama, harapan jangka pendek sebagai langkah awal adalah untuk merangsang tumbuhnya semangat swadaya dan partisipasi masyarakatbagi pondasi perubahan sosial yang berujung pada pemberdayaan masyarakat (empowering society), di antaranya adalah: 1). Terjadinya perubahan mindset dan jiwa konservasi dan wirausaha pada subyek dampingan, sehingga mereka sadar akan pentingnya konservasi sekaligus wirausaha dengan memanfaatkan tanah pekarangan rumah. 2). Lahirnya subyek dampingan yang memiliki seperangkat pengetahuan (knowledge) dan ketrampilan (life skill) untuk peningkatan nilai konservasi, nilai ekonomi, dan juga nilai ketahanan pangan yang berbasis pada potensi lokal. 3). Terjadinya perubahan dan terciptanya habituasi pola kerja subyek dampingan yang mengedepankan konsep kerja keras dan cerdas, yang pada akhirnya diharapkan bisa meningkatkan produktifitas. 4). Lahirnya kelompok subyek dampingan sebagai sebuah teamwork yang memiliki kesadaran dan semangat yang tinggi, serta memiliki cita-cita bersama untuk membangun budaya konservasi dan budaya wirausaha untuk mendukung ketahanan pangan.

Kedua, harapan jangka menengah, merupakan kelanjutan dari apa yang sudah dicapai pada harapan jangka pendek. Harapan jangka menengah ini antara lain: 1). Meningkatnya nilai konservasi lahan dan juga nilai ekonomi lahan yang dimiliki oleh masyarakat / subyek dampingan, sehingga meningkatkan kesejahteraan ekonomi rumah tangga. 2). Terbukanya peluang kerjasama dengan pihak pemerintah maupun swasta, baik dalam akses permodalan maupun dalam pengembangan usaha ekonomi produktif yang berbasis pada potensi lokal.

Ketiga, harapan jangka panjang, merupakan kelanjutan dari apa yang sudah dicapai pada harapan jangka menengah. Harapan jangka panjang ini adalah terbentuknya Kampung Tematik berbasis Konservasi dan Wirausaha Agribisnis guna mendukung Kelurahan Kedungpane sebagai Desa Wisata di Kota Semarang.

Program pemberdaaan masyarakat merupakan sebuah proses panjang yang dilakukan secara berjenjang dan berkelanjutan, sehingga tidak mungkin dicapai dalam waktu yang relatif singkat dan cepat. Oleh karena itu program kegiatan Karya Pengabdian Dosen (KPD) Tahun 2017 ini, hanyalah merupakan langkah awal untuk membangun pondasi yang kuat dalam rangka menyiapkan pilar struktur dan kultur bagi pemberdayaan masyarakat. Sebagai sebuah pondasi tentu saja belum banyak capaian harapan yang bisa dilihat secara fisik-materiil 
dalam bentuk perubahan penghasilan ekonomi subyek dampingan. Oleh karenanya, harapan yang ingin dicapai melalui program Karya Pengabdian Dosen (KPD) tahun 2017 ini dapat dideskripsikan pada tabel 1.

Tabel 1

Kondisi dampingan sebelum dan sesudah proses pengabdian

\begin{tabular}{|c|c|c|}
\hline No & Kondisi Sebelum & Kondisi Sesudah \\
\hline 1. & $\begin{array}{l}\text { Subyek dampingan belum } \\
\text { memiliki } \\
\text { (knowledge) terkait masalah- } \\
\text { masalah degradasi lingkungan } \\
\text { dan langkah-langka } \\
\text { pencegahannya. }\end{array}$ & $\begin{array}{l}\text { Setelah mengikuti } \begin{array}{c}\text { program } \\
\text { pengembangan } \\
\text { pengetahuan tentang pemanfaatan }\end{array} \\
\text { tanah pekarangan untuk konservasi } \\
\text { dan wirausaha di kalangan subyek } \\
\text { dampingan mulai tumbuh, seiring } \\
\text { dengan meningkatnya motivasi dan } \\
\text { semangat untuk pemanfaatan tanah } \\
\text { pekarangan }\end{array}$ \\
\hline 2. & $\begin{array}{l}\text { Subyek dampingan belum } \\
\text { memiliki pengetahuan } \\
(\text { knowledge) terkait pemanfaatan } \\
\text { tanah pekarangan untuk } \\
\text { konservasi dan wirausaha } \\
\text { agribisnis. }\end{array}$ & $\begin{array}{l}\text { Setelah mengikuti program } \\
\text { pengembangan masyarakat, } \\
\text { pengetahuan tentang pemanfaatan } \\
\text { tanah pekarangan untuk konservasi } \\
\text { dan wirausaha di kalangan subyek } \\
\text { dampingan mulai tumbuh, seiring } \\
\text { dengan meningkatnya motivasi dan } \\
\text { semangat untuk pemanfaatan tanah } \\
\text { pekarangan. }\end{array}$ \\
\hline 3. & $\begin{array}{l}\text { Subyek dampingan belum } \\
\text { memiliki } 4 \text { seperangkat } \\
\text { keterampilan (skill) yang } \\
\text { memadahi di bidang } \\
\text { pemanfaatan tana pekarangan } \\
\text { (PTP) untuk konservasi dan } \\
\text { wirausaha agribisnis. }\end{array}$ & $\begin{array}{l}\text { Setelah mengikuti program } \\
\text { pengembangan masyarakat, subyek } \\
\text { dampingan memiliki kemampuan } \\
\text { teknis dan ketrampilan untuk } \\
\text { melakukan pemanfaatan tanah } \\
\text { pekarangan untuk konservasi dan } \\
\text { wirausaha agribisnis. }\end{array}$ \\
\hline 4. & $\begin{array}{l}\text { Subjek dampingan belum } \\
\text { memiliki keterampilan di bidang } \\
\text { pembuatan lubang resapan } \\
\text { biopori untuk menunjang } \\
\text { program pemanfaatan tana } \\
\text { pekarangan (PTP) untuk } \\
\text { konservasi lingkungan. }\end{array}$ & $\begin{array}{l}\text { Setelah mengikuti program } \\
\text { pengembangan masyarakat, subyek } \\
\text { dampingan memiliki kemampuan } \\
\text { teknis dan ketrampilan untuk } \\
\text { membuat lubang resapan biopori } \\
\text { secara terintegrasi dengan desain } \\
\text { rumah }\end{array}$ \\
\hline 5. & $\begin{array}{l}\text { Subjek dampingan belum } \\
\text { memiliki }\end{array}$ & $\begin{array}{l}\text { Setelah mengikuti program } \\
\text { pengembangan masyarakat, subyek }\end{array}$ \\
\hline
\end{tabular}




\begin{tabular}{|c|c|c|}
\hline No & Kondisi Sebelum & Kondisi Sesudah \\
\hline & $\begin{array}{l}\text { pembuatan pupuk kompos } \\
\text { organik, baik padat maupun cair } \\
\text { untuk menunjang program } \\
\text { pemanfaatan tana pekarangan } \\
\text { (PTP) untuk konservasi dan } \\
\text { wirausaha agribisnis. }\end{array}$ & $\begin{array}{l}\text { dampingan memiliki kemampuan } \\
\text { teknis dan ketrampilan untuk } \\
\text { membuat pupuk kompos organic } \\
\text { secara mandiri di masing-masing } \\
\text { rumah dengan memanfaatkan } \\
\text { sampa organik dan limbah rumah } \\
\text { tangga }\end{array}$ \\
\hline 6. & $\begin{array}{l}\text { Subjek dampingan belum } \\
\text { memiliki keterampilan di bidang } \\
\text { budidaya tanaman hortikultura } \\
\text { secara baik, baik dari sisi } \\
\text { pembibitan, perawatan, maupun } \\
\text { pemanenan untuk menunjang } \\
\text { program pemanfaatan tana } \\
\text { pekarangan (PTP) untuk } \\
\text { konservasi dan wirausaha } \\
\text { agribisnis. }\end{array}$ & $\begin{array}{l}\text { Setelah mengikuti program } \\
\text { pengembangan masyarakat, subyek } \\
\text { dampingan memiliki kemampuan } \\
\text { teknis dan ketrampilan untuk } \\
\text { budidaya tanaman hortikultura } \\
\text { secara mandiri }\end{array}$ \\
\hline 7. & $\begin{array}{l}\text { Subjek dampingan belum } \\
\text { memiliki konsep keterlibatan } \\
\text { masyarakat, terutama ibu-ibu } \\
\text { rumah tangga di dalam } \\
\text { mengembangkan Kampung } \\
\text { Tematik berbasis potensi lokal } \\
\text { untuk mewujudkan Desa Wisata } \\
\text { Kedungpane }\end{array}$ & $\begin{array}{l}\text { Setelah mengikuti program } \\
\text { pengembangan masyarakat, ada } \\
\text { keterlibatan dan partisipasi dari } \\
\text { subyek dampingan, terutama ibu- } \\
\text { ibu rumah tangga, di dalam } \\
\text { mengembangkan Kampung } \\
\text { Tematik berbasis potensi lokal } \\
\text { untuk mewujudkan Desa Wisata } \\
\text { Kedungpane }\end{array}$ \\
\hline
\end{tabular}

\section{STRATEGI PENGELOLAAN LAHAN PEKARANGAN UNTUK KONSERVASI}

Berdasarkan teori yang dikemukakan oleh David C. Korten bahwa pengembangan masyarakat harus menjadi upaya memberikan kontribusi pada aktualisasi potensi tertinggi kehidupan manusia (Zubaedi, 2013: 44). Beberapa asumsi yang dapat digunakan dalam rangka mewujudkan semangat ini akan dikemukakan sebagai berikut: Pertama, pengembangan masyarakat tidak dilihat sebagai suatu proses pemberian dari pihak yang memiliki sesuatu kepada pihak yang tidak memiliki. Kedua, pengembangan masyarakat mesti dilihat sebagai sebuah proses pembelajaran masyarakat (social learning) agar mereka dapat secara mandiri melakukan upaya-upaya perbaikan kualitas kehidupannya. Ketiga pengembangan masyarakat tidak mungkin dilaksanakan tanpa keterlibatan secara 
penuh oleh masyarakat itu sendiri. Keempat, pengembangan masyarakat selalu ditengarai dengan adanya pemberdayaan masyarakat.

Oleh karenanya, dalam pelaksanaan program Karya Pengabdian Dosen (KPD) ini digunakan strategi sebagai berikut. Pertama, Rembug Warga. Kegiatan ini dimaksudkan untuk menyamakan persepsi antara tim pelaksana program Karya Pengabdian Dosen (KPD) dengan masyarakat dan beberapa stake holders tentang konsep dan tujuan program, identifikasi masalah, identifikasi potensi lokal, identifikasi calon subyek dampingan, strategi pelaksanaan program, rencana kegiatan, mekanisme kerja, dan pembagian tugas antar stake holders.

Kedua, Workshop dan Bimbingan Teknis. Kegiatan ini dimaksudkan untuk membekali subyek dampingan agar memiliki pengetahuan dan ketrampilan yang cukup, serta untuk meningkatkan kapasitas subyek dampingan agar memiliki kemampuan teknis dan magerial dalam mengembangkan potensi lokal menjadi barang yang memiliki nilai jual lebih tinggi. Ketiga, Praktek Pengalaman Lapangan (PPL). Kegiatan PPL ini didesain sesuai dengan topik utama dalam konteks pemanfaatan tanah pekarangan untuk konservasi dan wirausaha agrobisnis, sehinggabertujuan antara lain: 1). Sebagai salah satu upaya untuk membangun kesadaran konservsi dan wirausaha dari subyek dampingan. 2). Memperdalam dan mengembangkan pengetahuan maupun ketrampilan yang sudah diperoleh subyek dampingan dalam kegiatan Workshop dan Bimbingan Teknis. 4). Untuk melihat dan terlibat secara langsung dalam pelaksanaan kegiatan dibidang pemanfaatan tanah pekarangan untuk konservasi dan wirausaha agribisnis melalui budidaya tanaman hortikultura di tanah pekarangan rumah.

Keempat, Monitoring dan Evaluasi (Monev). Kegiatan Monev ini dimaksudkan untuk memantau dan mengevaluasi perkembangan subyek dampingan baik secara formal, semi formal, maupun informal selama mengikuti tahapan proses kegiatan pemberdayaan masyarakat. Dan kelima, Evaluasi dan Penyusunan Program Tindak Lanjut (Follow Up). Kegiatan ini dimaksudkan untuk mengevaluasi seluruh proses dan hasil pelaksanaan kegiatan pemberdayaan masyarakat berbasis potensi lokal melalui program Karya Pengabdian Dosen (KPD), sekaligus untuk merumuskan program tindak lanjut (follow up).

\section{PEMBERDAYAAN MASYARAKAT DAN PEMANFAATAN TANAH PEKARANGAN}

Pemberdayaan artinya memiliki atau mempunyai daya. Daya artinya kekuatan, berdaya memiliki arti kekuatan. Kata "berdaya" apabila diberi awalan pe- dengan mendapat sisipan - $\mathrm{m}$ - dan akhiran -an manjadi "pemberdayaan" artinya membuat sesuatu menjadi berdaya atau mempunyai kekuatan (Rosmedi 
dan Riza Risyanti, 2006: 1). Kata "pemberdayaan " adalah terjemahan dari bahasa Inggris "Empowerment", pemberdayaan berasal dari kata dasar "power" yang berarti kekuatan berbuat, mencapai, melakukan atau memungkinkan. Awalan "em" pemberdayaan dapat berarti kekuatan dalam diri manusia, suatu sumber kreativitas (Lili Baridi, Muhammad Zein, dan M. Hudri, 2007: 17).

Secara konseptual pemeberdayaan (emperworment) berasal dari kata power (kekuasaan atau keberdayaan) (Edi Sugarto, 2005: 57). Pemberdayaan menunjuk pada kemampuan orang. Khususnya kelompok rentan dan lemah sehingga mereka memiliki kekuatan atau kemampuan dalam: (a) memenuhi kebutuhan dasarnya sehingga mereka memiliki kebebasan (freedom), dalam arti bukan saja bebas mengemukakan pendapat, melainkan bebas dari kelaparan, bebas dari kebodohan, bebas dari kesakitan; (b) menjangkau sumber-sumber produktif yang memungkinkan mereka dapat meningkatkan pendapatannya dan memperoleh barang-barang dan jasa-jasa yang mereka perlukan; (c) berpartisipasi dalam proses pembangunan dan keputusan-keputusan yang mempengaruhi mereka(Edi Sugarto, 2005: 58). Konsep pemberdayaan tersebut juga tidak jauh berbeda dengan Moh. Ali Azis. Dia juga membagi konsep pemberdayaan menjadi tigayaitu: Pertama,pemberdayaan dengan menciptakan suasana atau iklim yang berkembang.Kedua, pemberdayaan untuk memperkuat potensi ekonomi atau daya yangdimiliki masyarakat. Dalam rangka memperkuat potensi ini, upaya yangamat pokok adalah peningkat taraf pendidikan, derajat kesehatan, sertaakses terhadap sumber-sumber kemajuan ekonomi, seperti modal,teknologi, informasi, lapangan kerja dan pasar. Ketiga, pemberdayaan melalui pengembangan ekonomi rakyat, dengan cara melindungi dengan mencegah terjadinya persaingan yang tidak seimbang serta menciptakan kebersamaan dan kemitraan antara yang sudah maju dengan yang belumberkembang (Moh. Ali Azis, dkk (ed), 2009: 170).

Menurut beberapa pakar yang terdapat dalam buku Edi Suharto, menggunakan difinisi pemberdayaan dilihat dari tujuan, proses, dan cara-cara pemberdayaan. Menurut Jim lfe dalam membangun masyarakat memberdayakan rakyat, pemberdayaan bertujuan untuk meningkatkan kekuasaan orang-orang yang lemah atau tidak beruntung(Edi Sugarto, 2005: 57). Masih dalam buku tersebut, person mengatakan bahwa pemberdayaan adalah sebuah proses dengan mana orang menjadi cukup kuat untuk berpartisipasi dalam mengontrol dan mempengaruhi terhadap kejadian-kejadian serta lembaga-lembaga yang mempengaruhi kehidupannya. Pemberdayaan menekankan bahwa orang memperoleh keterampilan, pengetahuan, dan kekuasaan yang cukup untuk mempengaruhi kehidupannya dan kehidupan orang lain yang menjadi 
perhatiannya. Sedangkan menurut Swift dan Levin dalam membangun masyarakat memberdayakan masyarakat, pemberdayaan menunjuk pada usaha pengalokasian kembali kekuasaan melalui pengubahan struktur sosial. (Edi Sugarto, 2005: 57). Definisi tentang pemberdayaan menurut para tokoh memang tidak jauh berbeda. Hal tersebut dapat dilihat tentang pengertian pemberdayaan berikut: 1). Adams sendiri mengartikan pemberdayaan sebagai alat untuk membantu individu, kelompok dan masyarakat supaya mereka mampu mengelola lingkungan dan mencapai tujuan mereka, sehingga mampu bekerja dan membantu diri mereka dan orang lain untuk memaksimalkan kualitas hidup, 2). pemberdayaan masyarakat merupakan suatu proses dimana masyarakat (khususnya yang kurang memiliki akses terhadap pembangunan) didorong untuk meningkatkan kemandiriandalam mengembangkan perikehidupan mereka. Model-model pemberdayaan: People Centre Development (i.e. IDT, Proyek Kawasan Terpadu (PKT), Proyek Peningkatan Pendapatan Petani dan Nelayan Kecil (P4K), Jaringan Pengaman Sosial (JPS), Raskin, BLT); Model Lingkaran Setan Kemiskinan; Model Kemitraan,dll. Hal ini dapat dilihat dalam bukunya Robert Adams, Social Work and Empowerment(Robert Adams, 2003), danAgus Surjono \& Trilaksono Nugroho, Paradigma, Model, Pendekatan Pembangunan, dan Pemberdayaan Masyarakat di Era Otonomi Daerah, (Agus Surjono \& Trilaksono Nugroho 2008:29).

Berdasarkan difinisi pemberdayaan di atas, maka dapat disimpulkan bahwa pemeberdayaan adalah serangkaiaan kegiatan untuk memperkuan kukasaan atau keberdayaan kelompok rentan dan lemah dalam masyarakat, termasuk individu-individu yang mengalami masalah kemiskinan, sehingga mereka memiliki keberdayaan dalam memenuhui kebutuhan hidupnya baik secara fisik, ekonomi, maupun sosial seperti: kepercayaan diri, maupun menyampaikan aspirasi, mempunyai mata pencahariaan, berpartisipasi dalam kegiatan sosial dan mendiri dalam melaksanakan tugas-tugas kehidupanya. Adapun cara yang di tempuh dalam malakuakan pemberdayaan yaitu dengan memberikan motivasi atau dukungan berupa sumber daya, kesempatan, pengetahuan, dan keterampilan bagi masyarakat untuk meningkatkan kapasitas mereka, meningkatkan kesadaran tentang potensi yang di milikinya, kemudian berupaya untuk mengembangkan potensi yang dimiliki tersebut.

Tujuan utama pemberdayaaan adalah memperkuat kekuasaaan masyarakat khususnya kelompok lemah yang memiliki ketidakberdayaan, baik karena kondisi internal (misalnya presepsi mereka sendiri), maupun karena kondisi eksternal (misalnya ditindas oleh struktur sosial yang tidak adil) (Soerjono Soekanto, 1987: 75). Ada beberapa kelompok yang dapat dikategorikan sebagai 
kelompok lemah atau tidak berdaya. Kelompok lemah secara stuktural, naik lemah secara kelas, gender, maupun etnis. Kelompok lemah khusus, seperti manula, anak-anak, dan remaja penyandang cacat, gay dan lesbian, masyarakat terasing. Dan Kelompok lemah secara personal, yakni mereka yang mengalami masalah pribadi atau keluarga (Edi Sugarto, 2005: 60).

Menurut Agus Syafiei, tujuan pemberdayaan masyarakat adalah mendirikan masyarakat atau membangun kemampuan untuk memajukan diri ke arah kehidupan yang lebih baik secara seimbang. Karena pemberdayaan masyarakat adalah upaya memperkuas horizon pilihan bagi masyarakat. Ini berarti masyarakat diberdayakan untuk melihat dan memilih sesuatu yang bermanfaat bagi dirinya (Agus Ahmad Syarfi'i,39).

Payne mengemukakan bahwa suatu proses pemberdayaan (empowerment), pada intinya bertujuan: membantu klien memperoleh daya untuk mengambil keputusan dan menemukan tindakan yang akan ia lakukan yang berkaitan dengan diri mereka, termasuk mengurangi efek hambatan peribadi dan sosial dalam melakuakan tindakan. Hal ini dilakukan melalui peningkatan kemampuan dan rasa percaya diri untuk menggunakan daya yang ia miliki, antara lain melalui trasfer daya dari lingkungannya.

Berdasarkan kajian konsep dasar pemberdayaan masyarakat yang dilanjutkan dengan mengkonstruksi konsep sebagai bagian dari upaya membangun paradigma baru model, maka pemberdayaan masyarakat harus mengikuti beberapa prinsip dasar, yaitu: Pertama, berorientasi pada kesejahteraan lahir dan batin masyarakat luas. Pemberdayaan masyarakat tidak dilaksanakan sekedar merumuskan keinginan sebagian masyarakat saja, tetapi direncanakan sebagai usaha membenahi kehidupan sosial bersama masyarakat agar penindasan, ketidakadilan, dan kesewenangan-wenangan tidak lagi hidup di tengah-tengah mereka. Kedua,pemberdayaan masyarakat pada dasarnya adalah upaya melakukan socialengineering (rekaya sosial) untuk mendapatkan suatu perubahan tatanan sosial kehidupan sosial yang lebih baik. Pemberdayaan masyarakat merupakan proses perencanaan perubahan sosial yang berlandaskan pada nilai-nilai yang berlaku di masyarakat. Sasaran utama pemberdayaan masyarakat lebih pada setting sosial kehidupan masyarakat daripada individuindividu. Landasan berpikir para ahli dalam melihat problem yang dihadapi masyarakat adalah sebuah permasalahan sosial yang oleh karena itu pemecahannya mesti dilaksanakan dalam skala kehidupan sosial.

Di samping kedua prinsip dasar tersebut ada beberapa prinsip lain yang harus terpenuhi dalam pemberdayaan masyarakat, antara lain prinsip kebutuhan artinya program pemberdayaan masyarakat harus didasarkan atas dan untuk 
memenuhi kebutuhan masyarakat. Kebutuhan di sini tidak hanya dipahami sebagai kebutuhan fisik material namun juga non material. Oleh karena itu program pemberdayaan masyarakat harus disusun bersama, baru kemudian dirumuskan pula metode materi dan medianya. Dengan demikian seseorang tidak lagi terasing dengan masyarakat sasaran. Konsep pemberdayaan masyarakat seperti inilah yang ditawarkan sebagai jawaban dan tuntunan kontekstualisasi pemberdayaan masyarakat.

Prinsip keterpaduan mencerminkan adanya upaya untuk memadukan seluruh potensi dan sumber daya yang dimiliki masyarakat. Dalam konteks inilah pemberdayaan masyarakat itu bukan monopoli sekelompok orang yang ahli atau organisasi, melainkan lebih luas dari itu yakni siapapun yang mempunyai komitmen community development yang berpijak pada universalitas nilai-nilai sosial adalah bagian dari seorang yang terjun dalam pemberdayaan masyarakat. Oleh karena itu, pemberdayaan masyarakat itu bersifat lintas budaya dan lintas sektoral. Untuk itulah intergrated or holistic strategy merupakan pilihan yang tepat dalam proses pengembangan masyarakat.

Dalampemberdayaan masyarakat ada sejumlah prinsip umum dan prinsip khusus yang harus dipegang oleh pihak-pihak yang melakukan kerja pemberdayaan masyarakat. Prinsip-prinsip umum pemberdayaan masyarakat dimaksud adalah: Pertama, buman dignity yakni keyakinan bahwa setiap manusia mempunyai kehormatan diri, harga diri, mempunyai rasa ingin dimuliakan dan dihargai. Kedua, self-determination yaitu setiap orang yang mengalami masalah mempunyai hak penuh untuk menentukan sendiri kebutuhannya dan bagaimana cara mengatasinya. Ketiga, equal opportunity yakni keyakinan bahwa setiap orang mempunyai kesempatan yang sama, yang hanya dibatasi oleh kemampuan masing-masing. Keempat, individualization yakni tidak menyamaratakan satu masyarakat dengan lainnya, karena suatu masyarakat atau kelompok orang dalam masyarakat kadang berbeda dengan yang lainnya. Kelima, participation yakni keharusan peran serta seluruh atau sebagain besar anggota masyarakat dalam suatu kerjasama. Keenam, transparansi dan akuntabilitas yakni pemberdayaan masyarakat membutuhkan sejumlah dana, dan karenanya keterbukaan dan laporan keuangan yang dapat dipertanggungjawabkan menjadi penting maknanya. Ketujuh, social responsibility yakni hak-hak seseorang untuk dihormati dan dihargai, hak menentukan nasib sendiri, dan kesempatan yang sama. Kedelapan, self-reliance yakni pentingnya membangun kepercayaan diri dari klien (Totok Mardikanto\& Poerwoko Soebiato, 2012:29).

Adapun prinsip-prinsip khusus pemberdayaan masyarakat adalah: Pertama, pengembangan masyarakat didasarkan atas kebutuhan dan untuk memenuhi 
kebutuhan tersebut. Kedua, bekerjasama dengan pihak-pihak yang dapat memberikan dukungan dan para relawan. Ketiga, mengutamakan usaha-usaha yang bersifat pencegahan. Keempat, memfasilitasi dan membangun kepercayaan pihak-pihak yang terlibat dalam pengembangan masyarakat.

Pemberdayaan masyarakat sebagai tahapan awal menuju kesuksesan masyarakat, menurut Drijver dan Sajise memiliki lima macam prinsip utama, yaitu: Pertama, pendekatan dari bawah (buttom up approach).Pada kondisi ini pengelolaan dan stakeholder sepakat pada tujuan yang ingin dicapai untuk kemudian mengembangkan gagasan dan beberapa tahapan kegiatan untuk mencapai tujuan yang telah dirumuskan sebelumnya. Kedua, partisipasi (participation) dimana setiap aktor yang terlibat memiliki kekuasaan dalam setiap fase perencanaan dan pengelolaan. Ketiga, konsep keberlanjutan (sustainability) yaitu merupakan pengembangan kemitraan dengan seluruh lapisan masyarakat sehingga program pembangunan berkelanjutan dapat diterima secara sosial dan ekonomi. Keempat, memiliki keterpaduan atau kohesivitas kebijakan dan strategi pada tingkat lokal, regional dan nasional. Kelima, keuntungan sosial dan ekonomi merupakan bagian dari program pengelolaan (Loekman Soetrisno, 1995: 17).

\section{PEMBERDAYAAN MASYARAKAT MELALUI PEMANFAATAN TANAH PEKARANGAN (PTP) UNTUK KONSERVASI DAN WIRAUSAHA AGRIBISNIS}

Sebelum tim pelaksana Karya Pengabdian Dosen (KPD) melakukan kegiatan di lapangan, maka pada tanggal 12 Juli 2017terlebih dahulu dilakukan kegiatan studi pendahuluan (preliminary research). Kegiatan ini dimaksudkan: Pertama, untuk mendapatkan informasi yang komprehensif tentang potret riil dan kondisi obyektif masyarakat yang akan menjadi sasaran program (subyek kegiatan). Kedua, untuk menggali problem yang dihadapi masyarakat, tanah pekarangan yang bisa dikembangkan, sumber daya yang ada, fasilitas sarana dan prasarana pendukung yang bisa dimanfaatkan, sehingga dengan demikian dapat dilakukan analisis problem solving, analisis tanah pekarangan dan pemetaan calon subyek dampingan. Ketiga, untuk mengetahui kebutuhan obyektif masyarakat yang akan menjadi sasaran program (subyek kegiatan). Keempat, untuk mengetahui sejauhmana visibilitas program pemberdayaan masyarakat melalui pemanfaatan tanah pekarangan untuk konservasi dan wirausaha agribisnis melalui kegiatan Karya Pengabdian Dosen (KPD).

Proses pelaksanaan studi pendahuluan dilakukan dengan cara mengadakan komunikasi dan koordinasi dengan pihak-pihak stakeholders yang 
terkait dan akan terlibat baik langsung maupun tidak langsung dalam program Karya Pengabdian Dosen (KPD) ini, antara lain:

a. Pemerintah di lingkungan Kelurahan Kedungpane yang terdiri dari Ketua RW dan Ketua RT, serta pengurus tim penggerak PKK RW dan RT masingmasing akan terlibat dalam membantu tim pelaksana program dalam hal seleksi calon subyek dampingan, menfasilitasi tempat dan perlengkapan kegiatan, dan pendampingan selama proses dan pasca pelaksanaan program.

b. Tim KPD akan terlibat dalam fasilitasi perlengkapan, peralatan pelatihan life skill, dan sarana-prasarana kegiatan karya pengabdian, pendampingan, dan pembinaan program tindak lanjut.

c. Dinas Pertanian Kota Semarang akan terlibat sebagai konsultan pengembangan dalam bidang budidaya tanaman hortikultura di tanah pekarangan Selain terlibat dalam pelatihan, juga sekaligus akan melatih dan mendampingi secara langsung subyek dampingan dalam proses praktek life skill, monitoring dan evaluasi hasil praktek life skill, pendampingan Praktek Pengalaman Lapangan (PPL), bimbingan teknis dalam membangun home industry, sampai dengan bimbingan teknis pengembangan usaha bagi subyek dampingan.

d. Lembaga Penanggulangan Bencana dan Perubahan Iklim (LPBI) Nadlatul Ulama Kota Semarang akan terlibat sebagai konsultan dalam bidang konservasi lingkungan.

e. Dinas Lingkungan Hidup (DLH) Kota Semarang akan terlibat sebagai konsultan dalam pembinaan dan pengembangan dibidang pembuatan lubang resapan biopori.

f. Badan Pemberdayaan Masyarakat Desa, Kependudukan dan Catatan Sipil (Bapermadesdukcapil) Propinsi Jawa Tengah akan terlibat sebagai konsultan program pengembangan masyarakat desa dan pembinaan pasca program dan sebagai fasilitator pelatihan managemen kelompok dan konsultan pengembangan masyarakat desa.

g. Dinas Koperasi dan UMKM Kota Semarang akan terlibat sebagai konsultan pengembangan usaha maupun dalam pembinaan dan pengembangan home industry subyek dampingan.

Kegiatan komunikasi dan koordinasi dilakukan melalui pertemuan formal dan informal dengan masing-masing pihak yang menjadi stakeholder sesuai dengan kapasitasnya masing-masing. Koordinasi itu dilakukan selain untuk mendapatkan informasi secara mendetail dan komprehensif tentang potret riil dan kondisi obyektif masyarakat yang akan menjadi sasaran program (subyek 
kegiatan), untuk menggali problem yang dihadapi masyarakat, tanah pekarangan yang bisa dikembangkan, sumber daya yang ada, fasilitas sarana dan prasarana pendukung yang bisa dimanfaatkan, untuk mengetahui kebutuhan obyektif masyarakat yang akan menjadi sasaran program (subyek kegiatan), juga untuk mengkomunikasikan kesediaan pihak-pihak stakeholders untuk membantu dan terlibat dalam program Karya Pengabdian Dosen ini, baik sebagai narasumber pelatihan, bimbingan teknis dalam praktek hasil pelatihan life skill, pendampingan dan monitoring-evaluasi (Monev), maupun dalam prospek pengembangan usaha.

Dari kegiatan komunikasi dan koordinasi dengan pihak-pihak stakeholders di atas, selanjutnya disusun langkah-langkah pelaksanaan program melalui beberapa tahapan kegiatan yang meliputi: 1) kegiatan rembug warga;2) pelatihan managemen kelompok; 3) pelatihanlife skill dan bimbingan teknis (bintek); 4) Praktek Pengalaman Lapangan (PPL) di Dinas Pertanian Kota Semarang; 5) monitoring dan evaluasi (monev) pelaksanaan program; 6) pemberian stimulan modal usaha; dan 7) evaluasi dan penyusunan program tindak lanjut (follow up).

Selanjutnya Rembug warga ini dilakukan untuk mendapatkan informasi yang lebih komprehensif dan guna mendapatkan dukungan penuh dari masyarakat dalam melaksanakan program Karya Pengabdian Dosen (KPD), maka terlebih dahulu pada tanggal 15 dan 22 Juli 2017 dilakukan kegiatan rembug warga. Rembug warga ini merupakan forumrapat koordinasi antara tim pelaksana program Karya Pengabdian Dosen (KPD) dengan warga yang menjadi sasaran program dan pihak-pihak stakeholders. Kegiatan ini dimaksudkan untuk menyamakan persepsi antara tim pelaksana program Karya Pengabdian Dosen (KPD) dengan masyarakat dan beberapa stake holders tentang konsep dan tujuan program, identifikasi masalah, identifikasi tanah pekarangan untuk konservasi dan dan wirausaha agribisnis, identifikasi calon subyek dampingan, strategi pelaksanaan program, rencana kegiatan, mekanisme kerja, dan pembagian peran antar stake holders.

Kegiatan pelatihan managemen kelompok ini dimaksudkan sebagai langkah awal untuk membangun kelompok yang kohesif dan memiliki komitmen bersama untuk pengembangan usaha yang berbasis pada potensi lokal. Dalam pelaksanaannya, kegiatan pelatihan managemen kelompok ini menggunakan metode dinamika kelompok (group dynamic) sebagai salah satu alat manajemen untuk menghasilkan kerjasama kelompok yang optimal, agar pengelolaan organisasi kelompok menjadi lebih efektif, efisien dan produktif. Sebagai sebuah metode, dinamika kelompok menjadikan setiap anggota kelompok semakin menyadari siapa dirinya dan siapa orang lain yang hadir 
bersamanya dalam kelompok dengan segala kelebihan dan kekurangannya masing-masing. Kesadaran semacam ini perlu diciptakan karena kelompok atau organisasi akan menjadi efektif apabila memiliki satu tujuan, satu cara tertentu untuk mencapai tujuan yang diciptakan dan disepakati bersama dengan melibatkan semua individu anggota kelompok tersebut sesuai dengan kemampuannya masing-masing.

Sebagai suatu proses, dinamika kelompok berupaya menciptakan situasi sedemikian rupa, sehingga membuat seluruh anggota kelompok merasa terlibat secara aktif dalam setiap tahap perkembangan atau pertumbuhan kelompok, agar setiap orang merasakan dirinya sebagai bagian dari kelompok dan bukan orang asing. Dengan demikian diharapkan bahwa setiap individu dalam organisasi kelompok merasa turut bertanggung jawab secara penuh terhadap pencapaian tujuan bersama dan dapat membangun kekuatan kolektif (collective power).

Tahapan yang dilakukan dalam kegiatan pelatihan managemen kelompok ini terdiri dari dua kegiatan utama yaitubina suasana dandinamika kelompok (group dynamic). Adapun proses pelaksanaan dan tahapan dari dua kegiatan tersebut secara singkat dapat dideskripsikan sebagi berikut. Pertama, Bina Suasana. Bina suasana merupakan proses untuk membangun suasana pelatihan agar lebih cair (tidak kaku), komunikatif, kondusif, serta terbangun interaksi dan kerjasama yang sinergis antara peserta dengan tim pelaksana dan fasilitator. Dengan bina suasana ini dimaksudkan agar tidak ada jarak antara peserta dengan fasilitator dan tim pelaksana, maupun antar peserta itu sendiri.

Metode yang digunakan dalam kegiatan bina suasana ini adalah self reflection, brain storming, dan role playing. Media yang dipakai adalah laptop, LCD, white board, board marker, sepidol kecil warna-warni, kertas plano, kertas kartu warna, isolatip, dan perlengkapan pendukung lainnya. Adapun pendekatannya menggunakan model pendekatan pendidikan orang dewasa atau lebih dikenal dengan pendekatan andragogy(participatorytraining). Daur participatory training dapat diilustrasikan pada gambar 1.

Kedua, Dinamika Kelompok (Group Dynamic). Kegiatan dinamika kelompok ini dimaksudkan sebagai langkah awal untuk membangun kelompok yang kohesif dan memiliki komitmen bersama untuk pengembangan usaha yang berbasis pada pemanfaatan tanah pekarangan. Dinamika kelompok (group dynamic) merupakan salah satu alat manajemen untuk menghasilkan kerjasama kelompok yang optimal, agar pengelolaan organisasi kelompok menjadi lebih efektif, efisien dan produktif. Sebagai sebuah metode, dinamika kelompok menjadikan setiap anggota kelompok semakin menyadari siapa dirinya dan siapa 
orang lain yang hadir bersamanya dalam kelompok dengan segala kelebihan dan kekurangannya masing-masing. Kesadaran semacam ini perlu diciptakan karena kelompok atau organisasi akan menjadi efektif apabila memiliki satu tujuan, satu cara tertentu untuk mencapai tujuan yang diciptakan dan disepakati bersama dengan melibatkan semua individu anggota kelompok tersebut sesuai dengan kemampuannya masing-masing.

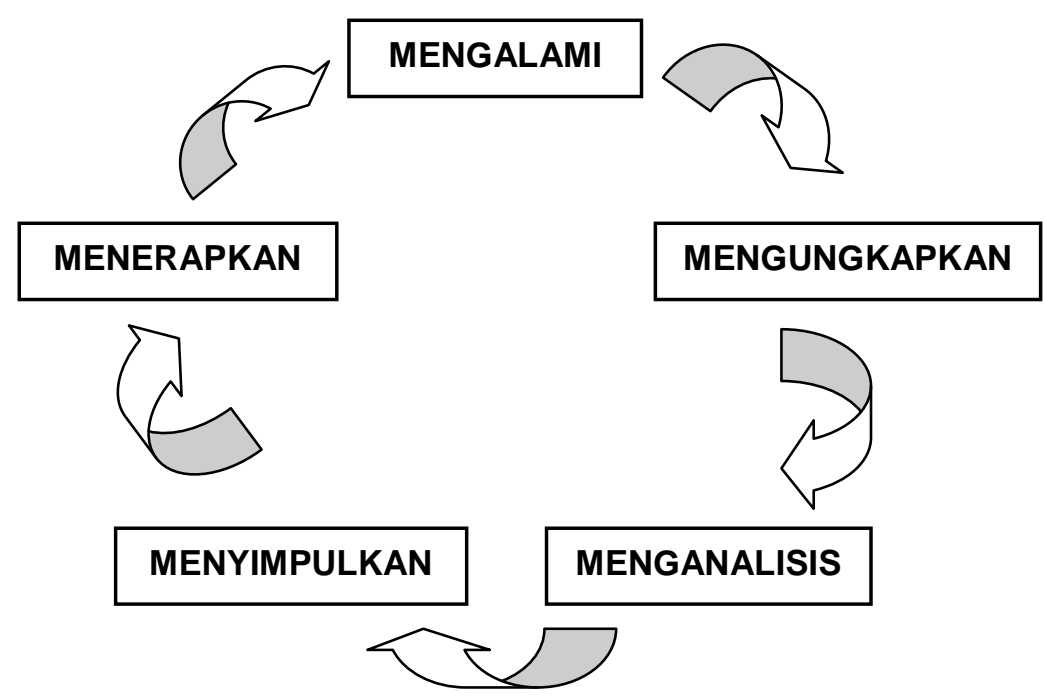

Gb. 1 daur participatory training

Sebagai suatu proses, dinamika kelompok berupaya menciptakan situasi sedemikian rupa, sehingga membuat seluruh anggota kelompok merasa terlibat secara aktif dalam setiap tahap perkembangan atau pertumbuhan kelompok, agar setiap orang merasakan dirinya sebagai bagian dari kelompok dan bukan orang asing. Dengan demikian diharapkan bahwa setiap individu dalam organisasi kelompok merasa turut bertanggung jawab secara penuh terhadap pencapaian tujuan bersama dan dapat membangun kekuatan kolektif (collective power).

Materi dinamika kelompok ini penting diberikan kepada subyek dampingan sebelum mereka memulai melakukan kerja-kerja berbasis kelompok. Materi dinamika kelompok ini penting diberikan kepada subyek dampingan dalam rangka untuk:

a. Menjelaskan kepada subyek dampingan tentang hubungan antar individu dalam sebuah tim (kelompok). 
b. Menjelaskan kepada subyek dampingan tentang posisi individu dalam sebuah tim (kelompok).

c. Menjelaskan kepada subyek dampingan tentang pentingnya kerjasama antar individu dalam sebuah tim (kelompok).

Adapun fungsi dinamika kelompok itu sendiri dalam konteks kerja-kerja berbasis kelompok antara lain:

a. Agar tercipta iklim demokratis, kesetaraan (equality), semangat saling memberi, dan kesadaran yang tinggi dari semua anggota kelompok yang terlibat dalam suatu kegiatan bersama.

b. Agar terbangun ikatan jiwa antar anggota kelompok sehingga akan tercipta kepaduan sosial (social cohesion) yang kuat antar subyek dampingan dalam sebuah tim .

c. Agar terbangun komitmen bersama untuk melakukan semua pekerjaan yang menjadi tanggungjawab kelompok, sehingga dapat tercapai tujuan bersama dengan efektif dan efisien.

d. Agar tercipta suasana kompetitif yang sehat sehingga merangsang setiap anggota kelompok untuk bekerja lebih maksimal dan produktif.

Metode yang digunakan dalam dinamika kelompok (group dynamic) ini adalah self reflection, brainstorming, dan role playing. Media yang dipakai adalah laptop, LCD, white board, board marker, sepidol kecil, kertas plano, kertas kartu warna, isolatip, lembar formulir sosiogram, dan perlengkapan pendukung lainnya. Adapun pendekatannya menggunakan model pendekatan pendidikan orang dewasa atau lebih dikenal dengan pendekatan andragogy(participatorytraining).

Untuk mencapai tujuan materi di atas, maka dalam penyampaiannya fasilitator melakukan beberapa tahapan sebagai berikut:

a. Fasilitator membuka acara (memotivasi) dan menjelaskan tujuan materi.

b. Fasilitator dibantu tim pelaksana membagikan kertas kartu warna kepada peserta untuk menulis nama masing-masing dan ditempelkan di papan tulis.

c. Fasilitator membagi peserta menjadi dua kelompok.

d. Fasilitator membagi formulir sosiogram kepada masing-masing peserta.

e. Peserta diminta untuk mengisi formulir sosiogram.

f. Peserta diminta membacakan hasil pilihannya disertai alasannya. Bersamaan dengan itu, masing-masing menulis posisi yang disampaikan atau ditunjuk oleh peserta lain. Sementara itu fasilitator membuat garis hubungan peserta dengan tanda panah.

g. Fasilitator meminta peserta menyampaikan "apa yang sulit ditentukan", "apa yang ragu-ragu”, "apa yang mudah". Jawaban peserta ditulis di papan tulis.

h. Fasilitator menskors pilihan-pilihan posisi dan mengoreksi hasil skor. 
i. Fasilitator menanyakan perasaan peserta.

j. Fasilitator menarik pelajaran kaitannya dengan hubungan dan posisi antar peserta.

k. Fasilitator menyimpulkan seluruh proses.

Ketiga, PelatihanLife Skill dan Bimbingan Teknis. Kegiatan Pelatihan Life Skill dan Bimbingan Teknis (Bintek) yang diselenggarakan pada tanggal 5 - 6 Agustus 2017 ini sebagai moderator adalah Bapak Agus Riyadi, M.SI dan pamateri adalah Bapak Rosmadi, M.Si dari Tim Pelaksana Program KPD. Pelatihan dimaksudkan untuk membekali subyek dampingan agar memiliki pengetahuan dan ketrampilan yang cukup dalam memanfaatkan tanah pekarangan agar menjadi tempat yang memiliki nilai jual lebih tinggi. Pemilihan tema Pelatihan Life Skill dan Bimbingan Teknis (Bintek) berdasarkan kesepakatan seluruh anggota kelompok subyek dampingan adalah pembuatan hidroponik. Hal ini didasari beberapa pertimbangan sebagai berikut: Pertama, tanah pekarangan yang dimiliki oleh warga kelurahan Kedungpane mayoritas masih luamayan luas, sehingga dapat digunakan sebagai tempat untuk menanam sayuran menggunaakan media hidroponik dan juga bisa ditanami buah-buahan seperti durian, nangka, pisang, dll. Dengan kata lain, pemanfaatan tanah pekarangan menjadi pertimbangan utama selaras dengan tema Karya Pengabdian Dosen (KPD) ini yaitu pemberdayaan masyarakat melalui pemanfaatan tanah pekarangan untuk konservasi dan dan wirausaha agribisnis. Kedua, banyaknya bahan bekas seperti kaleng, plastic, dan pipa pralon yang bisa digunakan sebagai bahan untuk untuk pembuatan hidroponik.

PelatihanLife Skill dan Bimbingan Teknis (Bintek)pembuatan hidroponik ini menggunakan metode ceramah, tanya jawab (konsultasi), dan praktek. Media yang dipakai adalah laptop, LCD, white board, board marker, kertas plano, isolatip, pipa pralon, kaleng bekas, plastikdan peralatan pendukung lain, bahanbahan praktek hidroponik. Adapun pendekatannya menggunakan model pendekatan pendidikan orang dewasa atau lebih dikenal dengan pendekatan andragogy (participatorytraining).

Untuk mendapatkan hasil yang maksimal, maka dalam Pelatihan Life Skill dan Bimbingan Teknis (Bintek) pembuatan hidroponik ini, tim pelaksana program karya pengabdian menghadirkan seorang trainer yaitu Bapak Nadi, M.Si (Kabag Bapermadesdukcapil Propinsi Jawa Tengah).Ia bukan saja sudah sangat berpengalaman dalam kegiatan training pebuatan hidroponik, namun juga sekaligus sebagai pelaku bisnis di bidang itu yang sudah sukses.

Tahapan yang dilaksanakan dalam Pelatihan Life Skill dan Bimbingan Teknis (Bintek) pembuatan hidroponik ini meliputi: Pertama, pendahuluan. 
Kedua, penyampaian materi dan praktek. Ketiga, evaluasi hasil praktek. Adapun materi yang disampaikan beserta praktek life skill dan Bimbingan Teknis (Bintek)terdiri dari: 1). Pengenalan bahan pembuatan hidroponik, 2) Media tanah yang digunakan, 3) cara menanam biji-bijian sayuran).

Keempat, Praktek Pengalaman Lapangan. Kegiatan PPL dalam konteks pengembangan masyarakat berbasis pemanfaatan tanah pekarang ini memiliki beberapa maksud dan tujuan. Sebagai salah satu upaya untuk membangun jiwa entrepreneur subyek dampingan, sehingga mereka memiliki motivasi dan semangat yang tinggi untuk merintis, memulai dan mengembangkan usaha produksi aneka makanan berbasis tanah pekarangan. Untuk membuka wawasan baru para subyek dampingan tentang berbagai peluang dan prospek bisnis makanan dan minuman berbasis tanah pekarangan yang bisa dikembangkan bersama melalui kelompok yang sudah dibentuk. Untuk memperdalam dan mengembangkan pengetahuan maupun ketrampilan yang sudah diperoleh subyek dampingan dalam kegiatan pelatihan life skill pada tanggal 5 - 6Agustus 2017. Dan untuk melihat dan terlibat secara langsung dalam pelaksanaan proses produksi aneka makanan dan minuman berbasis pemanfaatan tanah pekarangan yang dilakukan di Desa Rowosari Kecamatan Tembalang Kota Semarang, mulai dari tahap persiapan, pemilihan bahan, proses produksi, proses quality control, hingga tahap proses packing (pengemasan hasil produksi). Dengan cara seperti ini maka subyek dampingan akan mendapatkan pengetahuan dan ketrampilan yang lebih komprehensip sebagai modal dasar untuk merintis dan memulai usaha.

Untuk mendapatkan gambaran tentang managemen usaha yang diterapkan di Desa Rowosari Kecamatan Tembalang Kota Semarang, sehingga bisa dijadikan bekal subyek dampingan dalam rangka merintis dan memulai usaha.

\section{KESIMPULAN}

Pelaksanaan kegiatan pemberdayaan masyarakat berbasis pemanfaatan tanah pekarangan untuk konservasi dan wirausaha agribisnis dapat diambil kesimpulan sebagai berikut:

1. Dalam melakukan kerja-kerja pemberdayaan masyarakat (community development), tim pelaksana melihat sifat organik masyarakat itu sendiri. Tugastim pelaksana program sebagai orang luar (outsider) adalah mendorong terjadinya percepatan pemberdayaan dengan memahami proses dan struktur yang ada di masyarakat, dan menghargai keunikan setiap masyarakat. Sebagai konsekuensi dari sifat organik masyarakat, maka program pemberdayaan masyarakat (community development) harus dilakukan secara bertahap. 
Pemberdayaan masyarakat bukan suatu proses yang cepat dan instan, sebab memaksakan agenda dengan cepat justru akan menyebabkan masyarakat bukan menjadi pemilik program. Program pemberdayaan masyarakat merupakan proses pembelajaran bagi masyarakatnya, bukan suatu upaya instan dari pihak luar yang mengajukan resep perubahan.

2. Masyarakat pedesaan masih sangat kental dengan nilai-nilai kultur sosialnya, seperti kebersamaan dan gotong royong, suka tolong-menolong, bekerja tanpa pamrih, solidaritas yang tinggi terhadap sesama, suka kemitraan dengan menganggap siapa saja sebagai saudara. Selain itu masyarakat pedesaan juga memiliki tradisi suka bekerja keras (etos kerja tinggi). Potensi besar ini jika distimulasi dengan program pemberdayaan masyarakat melalui berbagai pelatihan life skill dan pelatihan-pelatihan lain untuk meningkatkan kapasitas sumber daya manusia (SDM), akan melahirkan komunitas masyarakat pedesaan yang bisa mengembangkan ekonomi produktif dan kreatif berbasis kelompok dan keluarga.

3. Beberapa perubahan yang sudah dicapai melalui program KPD ini adalah: 1) Terjadinya perubahan sikap mental dan pola pikir (mindset) dan jiwa entrepreneur pada subyek dampingan, sehingga mereka sadar akan adanya potensi lokal di sekelilingnya yang bisa dikembangkan menjadi komuditas yang bernilai jual tinggi. 2) Terjadinyaperubahan dan terciptanya habituasi pola kerja subyek dampingan yang mengedepankan konsep kerja keras dan cerdas, yang pada akhirnya diharapkan dapat meningkatkan produktifitas. 3) Lahirnya subyek dampingan yang memiliki seperangkat pengetahuan dan ketrampilan (life skill) untuk mengembangkan potensi lokal menjadi komoditas hasil produksi yang memiliki nilai jual lebih tinggi. 5) Lahirnya kelompok subyek dampingan sebagai sebuah teamwork yang memiliki kesadaran dan semangat yang tinggi, serta memiliki cita-cita bersama untuk membangun home industry yang dapat memproduksi kekayaan melalui pemanfaatan tanah pekarangan menjadi komuditas ekonomi yang bernilai jual tinggi.[] 


\section{DAFTAR PUSTAKA}

Agus Ahmad Syarfi; ${ }^{e} I$, Menejemen Masyarakat Islam, (Bandung: Gerbang Masyarakat Baru).

Agus Surjono, \& Trilaksono Nugroho, Paradigma, Model, Pendekatan Pembangunan, dan Pemberdayaan Masyarakat di Era Otonomi Daerah, (Malang: Bayumedia Publishing, 2008).

Anonim, Pedoman Umum Pemanfaatan Pekarangan. http://kambing.ui.ac.id/bebas/v12/artikel/pangan/DEPTAN/Ne w Folder/II/Pedum Pengembangan Pekarangan-.doc.(9/10/17).

Anonim, Vertikultur Cara Tanam Bertingkat PemanfaatanLahan Pekarangandi Perkotaan,http://goelagoela.blogspot.com/2011/03/vertikulturcara-tanam-bertingkat.html(4/10/2017)

Arifin, Hadi Susilo Arifin,Pemanfaatan Pekarangan di Perdesaan Buku Seri II, (Bogor: Biro Perencanaan Departemen Pertanian,2009).

Danoesastro H.. "Tanaman Pekarangandalam Usaba Meningkatkan KetahananRakyat Pedesaan". Agro-Ekonomi

Maret1999.http://endrymesuji.blogspot.com/2012/05/sistempekarangan.html . (25 September2017).

Dinas Pertanian Jatim. Rumah Hijau dalam Rangka Optimalisasi Pemanfaatan Pekarangan diPropinsi Jawa Timur, (Dinas Pertanian Propinsi Jawa'Timur, 2011).

Edi Sugarto, Membangun Masyarakat Memberdayakan Rakayat Kajian Strategis PembangunanKesejabteraan Sosial Dan Pekerja Sosial,(Bandung: PT Ravika Adimatama 2005), Cet Ke-1.

Hosen, N., Potensi dan Masalah Pengembangan Lahan Pekarangan Mendukung Peningkatan Produksi Buah-Buahan di Sumatera Barat, Prosiding Seminar Hortikultura,(Puslitbang Horti, 2008). 
Lakitan,

B. Pengembangan

Pola

PemanfaatanLahanPekarangansebagaiSumber Pendapatan dan Gizi Keluarga di Pedesaan Sumatera Selatan, 2012. Lihat dihttp:/ / libraryunsri.

Lili Baridi, Muhammad Zein, dan M. Hudri, Zakat Dan Wirausaha, (Jakarta: CED, 2007).

Loekman Soetrisno, Menuju Masyarakat Partisipatif, (Yogyakarta: Penerbit Kanisius, 1995).

Mardikanto, T dan Sri Sutarni, Pengantar Penyuluban Pertanian,(Surakarta: LSP3 1982).

Moh. Ali Azis, dkk (ed), Dakwah Pemberdayaan Masyarakat; Paradigma Aksi Metodologi, (Yogyakarta: LKis, 2009).

Novitasari, E, Studi Budidaya Tanaman Pangan Di Pekarangan Sebagai Sumber Ketahanan Pangan Keluarga (studi Kasus di Desa Ampel Gading Kecamatan Tirtoyudo Kabupaten Malang), (Malang: Skripsi. Universitas Brawijaya, 2011).

Penny, D.H. dan M. Ginting, Pekarangan Petani dan Kemiskinan, (Gadjah Mada University Press. Yayasan Agro Ekono- mika, 1984).

Rahayu, M. dan S. Prawiroatmodjo, Keanekaragaman Tanaman Pekarangan dan Pemanfaatannya di Desa Lampeapi, Pulau Wawoni Sulawesi Tenggara, (P3TL-BPPT, 2005).

Robert Adams, Social Work and Empowerment. 3rd ed.( New York: Palgrave Macmillan, 2003)

Rosmedi dan Riza Risyanti, Pemberdayaan Masyarakat, (Sumedang: Alqaprit Jatinegoro, 2006).

Sajogyo, Menuju Gizi Baik Yang Merata di PedesaandanDiKota,( Yogyakarta: GajahMadaPress, 1994). 
Saliem, H.P, Peranan Wanita dalam Sistem Produksi Pertanian Menunjang Program Diversifikasi Pangan dan Gizi. Dalam Suryana et al (Eds). Hlm 85-102. Monograp Series No 17. Kebijaksanaan Pembangunan Pertanian: Analisis Kebijaksanaan Antisipatif dan Responsif,(Pusat Penelitian Sosial Ekonomi Pertanian, Badan Penelitian dan Pengem- bangan Pertanian, 1997).

Saptana, T.B. Purwantini, Y. Supriyatna, Ashari,A.M. Ar-Razy, T. Nurasa, S. Suharyono, IW. Rusastra, S. H. Susilowati dan J. Situmorang, Dampak Pengem- bangan Model Kawasan Rumah Pangan Lestari Terhadap Kesejabteraan Rumah Tangga dan Ekonomi di Perdesaan, (Laporan Penelitian. Pusat Sosial Ekonomi danKebijakanPertanian.BadanPenelitian dan PengembanganPertanian, 2011).

Simatupang, P. dan A. Suryana, Literature Review of Socio-Economic Aspects of Pekarangan Land in Indonesia. Repotr Submitted to FAO/UN Jakarta Office, (Bogor: UnderSpesialServiceAgreementContract o TCP/INS/8852, Development of Pekarangan Lands, 1989)

Soelaiman, M. Munandar, Dinamika Masyarakat Transisi: Mencari Alternatif Teori Sosiologi dan Arah Perubahan,(Yogyakarta: Pustaka Pelajar, 1998).

Soerjono Soekanto, Sosial Suatu Pengantar, (Jakarta, Rajawalipress, 1987), Cet. Ke (a). 2 .

Suryana,A, Tantangan dan Kebijakan Ketahanan Pangan. Makalah disampaikan pada Seminar Nasional Pemberdayaan Masyarakat untuk Mencapai Ketahanan Pangan dan Pemulihan Ekonomi, (Departemen Pertanian, 29 Maret 2001).

TotokMardikanto\& Poerwoko Soebiato, Pemberdayaan Masyarakat dalam Perspektif Kebijakan Publik, (Bandung: Alfabeta, 2012).

Venkataraman, R, Household Gardening in Asia: A Review,(Working Paper No.3. Asian Vegetable Research and Development Center, 1992).

Zubaedi, Pengembangan Masyarakat W acana \& Praktik, (Jakarta: Kencana, 2013). 